\title{
Monetary Anticipations and the Demand for Money: An Application for the South Asian Region
}

\author{
Ather Maqsood Ahmed and Mohammad RafiQ*
}

\section{INTRODUCTION}

While there are a number of issues in economics which are frequently scrutinized, the most important of them probably is the determination of a stable money demand function. Other issues in this regard relate to the choice between (i) broad vs narrow definition of money; (ii) measured vs.permanent income; (iii) short-term vs. long-term interest rate; and (iv) inclusion of a variable for inflation or expected inflation.

Quite recently, a new dimension has been added to the demand for money function. It is now argued that unanticipatory changes in the nominal money supply also affect the real demand for money. Darby (1972) has proposed that unanticipatory nominal money supply behaves as a shock-absorber in the money demand function. Initially, Laidler (1980) and then Carr and Darby (1981) formulated a shock-absorber model in which they have shown empirically that unanticipatory shocks in money supply positively affect the demand for money. Inclusion of this shock variable was justified by Darby (1972) on the ground that money balances serve as a buffer stock or shock-absorber which temporarily absorbs unexpected variations in income, especially the transitory income, until an adjustment is reached in adjusting the portfolio of securities and in consumer durable goods. The shockabsorber model of Carr and Darby is based on the following two hypotheses:

(i) Changes in money supply which are fully anticipated will be reflected in price level expectations and, therefore, in nominal demand; and

(ii) Changes in money supply which are unanticipated will temporarily be stored in bank accounts. The adjustment in interest rates and the price level will not be so quick, so that money demand equals money supply.

*The authors are Research Economist and Computer Programmer respectively at the Pakistan Institute of Development Economics. They are grateful to Prof S.I. Cohen for helpful suggestions on an earlier draft of this paper. 
Therefore, these unexpected changes in money supply will affect real money balances with positive sign.

The second hypothesis was tested by Carr and Darby (1981) for eight industrial countries. Their results show that unanticipated money supply changes always positively affect the real demand for money. Furthermore, this particular result is insensitive to the estimation techniques.

Mackinnon and Milbourne (1984), while commenting on the Carr and Darby paper have shown that the econometric technique used by them yield severely biased estimates. Mackinnon and Milbourne (1984) arrived at this result after making a number of algebraic manipulations to the original model. However, in a later article Carr, Darby and Thornton (1985) refuted the comments of Mackinnon and Milbourne on the grounds that the economics used by the later to clarify their position was wrong. In the process, Carr, Darby and Thornton (1985) not only proved their second hypothesis as correct, they also proved that their first hypothesis was also correct. An attempt similar to the above was also made by Khan (1980). In this article a monetary anticipation model was estimated for a developing economy.

The present exercise is taken up with a view to put the hypotheses of the CarrDarby Model to further empirical testing for developing countries of the South Asian region. For this purpose, time-series data have been collected for the relevant variables for Pakistan, India, Sri Lanka and Bangladesh. ${ }^{1}$

The plan of the paper is as follows. The paper is divided into four parts. After the introduction and a brief review of literature, the second part outlines the proposed model. The third part reports the methodological issues and the results of estimation, while the last part concludes this study.

\section{THE PROPOSED MODEL}

The conventional real money demand function as given by Cagan (1956) is usually expressed as a Cobb-Douglas type function of a scale variable (usually current or permanent income) and one or more interest rate variables. The general form of the equation where all the variables are real and are expressed in logarithmic form is given as follows:

$$
m_{t}^{d}=\propto_{0}+\propto_{1} y_{t}+\propto_{2} r_{t} \quad \ldots \quad \ldots \quad \ldots
$$

\footnotetext{
${ }^{1}$ Data in this study covers a period from 1960 to 1982 . The authors are thankful to Mr Muslehuddin, Staff Economist, PIDE for providing the necessary data for this study.
} 
where

$$
\begin{aligned}
& m_{t}^{d}=M_{t}-P_{t}=\text { logarithm of real money demand; } \\
& y_{t}=Y_{t}-P_{t}=\text { logarithm of real income; } \\
& r_{t}=\text { logarithm of interest rate; } \\
& P_{t}=\text { logarithm of price level } ; \text { and } \\
& M_{t}=\text { logarithm of nominal money demand. }
\end{aligned}
$$

We assume that there is a tendency of partial adjustment of actual to the desired level of money stock. The partial adjustment model as proposed by Chow (1966) is

$$
m_{t}-m_{t-1}=\lambda\left(m_{t}^{d}-m_{t-1}\right) \quad \ldots \quad \ldots \quad \ldots
$$

Combining Equation (2) with Equation (1), we get the usual real money demand equation where there is a lagged dependent variable along with other exogenous variables. The new equation, after substitution, is the following:

$$
m_{t}=\beta_{0}+\beta_{1} y_{t}+\beta_{2} r_{t}-\beta_{8} m_{t-1} \quad \ldots \quad \ldots \quad \ldots
$$

As stated by Darby and Carr (1981), the Chow model is also consistent with contemporaneous changes in expected nominal money supply and price level, but it does not work so well when there are nominal money shocks. To incorporate this type of expression, they have developed the following relationship. Assume that $M_{t}^{s}$ is the logarithm of nominal money supply and $M_{t}^{a}$ is the anticipatory value of $M_{t}^{s}$. The hypothesis states that real money holding is not simply related to real money demand as in Equation (3) but it also includes a term for unanticipated value of money as in the extended Equation (4), i.e.,

$$
m_{t}=\beta_{0}+\beta_{1} y_{t}+\beta_{2} r_{t}+\beta_{3} m_{t-1}+\propto\left(M_{t}^{s}-M_{t}^{a}\right) \ldots \ldots
$$

The second type of modification in the original model as proposed by Carr and Darby is the addition of a term for transitory income. The reason for the inclusion of this variable as suggested by Darby (1972) is that all unexpected variations of 
income, especially the transitory income, are absorbed by money balances until there is final adjustment in the portfolio of securities.

Finally, the new proposed model can be differentiated from Equation (3) by making a choice for permanent income in place of current income. Therefore, after introducing the two changes, i.e. the choice of permanent income in place of measured income and by adding the transitory income in Equation (4), we get the following expression;

$$
m_{t}=\gamma_{0}+\gamma_{1} y_{t}^{p}+\gamma_{2} y_{t}^{T}+\gamma_{3} r_{t}+\gamma_{t} m_{t-1}+\propto\left(M_{t}^{s}-M_{t}^{a}\right)
$$

where

$$
\begin{aligned}
& y_{t} \simeq y_{t}^{p}+y_{t}^{T} \\
& y_{t}^{p}=\text { logarithm of permanent income; and } \\
& y_{t}^{T}=\text { logarithm of transitory income }
\end{aligned}
$$

\section{METHODOLOGICAL ISSUES}

Before we could proceed with the ultimate results of Equation (5), it may be important to clarify some of the steps that we have undertaken while estimating the model. The first step was the estimation of an unanticipated money supply variable. To calculate this variable, the first requirement was to estimate some kind of money demand function. In Carr and Darby (1981) a univariate ARIMA process was used. However, Mackinnon and Milbourne (1984) used only the lagged values of $M_{t}$ to find out the value of anticipatory money supply. They later on showed that the empirical results of these two estimation techniques did not change the conclusions to be drawn therefrom.

In the present study, the extrapolative predictors were obtained by regressing the actual money demand on its own past values. The number of lags were different for every country. We continued to add lags until the explanatory power of the equation $\left(\bar{R}^{2}\right)$ declined. This kind of prediction is regarded as 'partly rational' a term introduced by Sargent (1973). After adopting the above procedure, we first calculated the anticipatory values of money supply, i.e., $M_{t}^{p}$, and, in the second step, the unanticipatory money supply value was calculated by the relationship $M_{t}=M_{t}^{s}-M_{t^{\prime}}^{p}$ 
i.e. this is the residual in the above equations, which will now be used as a proxy for the shock variable in Equation (5). ${ }^{2}$

The second problem related to the estimation of permanent income. For this Purpose we used the methodology which was suggested by Rausser and Laumas (1976) and later on was used by Mangla (1979). Here the permanent income was defined as the weighted average of current and past income, ${ }^{3}$ i.e.,

$$
Y_{t}^{p}=0.4 Y_{t}+0.3 Y_{t-1}+0.2 Y_{t-2}+0.1 Y_{t-3}
$$

The transitory income can now be calculated from the relationship given below:

$$
Y_{t}^{T}=Y_{t}-Y_{t}^{p}
$$

where

$Y_{t}^{T}$ is logarithmic transitory income;

$Y_{t}$ is logarithmic current income; and

$Y_{t}^{p_{\text {is }} \text { logarithmic permanent income. }}$

The final problem relates to the estimation of Equation (5) itself. We have initially estimated this equation by the Ordinary Least Squares (OLS) technique. Since many variables like $\left(M_{t}, Y_{t}^{p}\right.$ and $Y_{t}^{T}$ are all simultaneously determined, there is a possibility that the estimated results of OLS have a simultaniety bias. To overcome the problem of simultaniety, we used the instrumental variable estimation technique. ${ }^{4}$

\section{ESTIMATION RESULTS OF THE MODEL}

Although there are a number of studies especially for Pakistan, India and Sri Lanka where the conventional money demand function is empirically tested, however, the focus of attention in almost all of these studies has revolved around testing alternative specifications. ${ }^{5}$

\footnotetext{
${ }^{2}$ Alternative specifications using dummy and fiscal variables were also tried, but unfortunately, neither of these worked well.

${ }^{3}$ Permanent income can also be measured by alternative methodology which can be found in the studies of Friedman (1959); Goldfeld (1973) and Laidler (1977). The choice between these alternatives is purely arbitrary.

${ }^{4}$ The choice of instruments in this study differs not only from Carr and Darby (1981), it also slightly differs from Mackinnon and Milbourne (1984). Here we have used the procedure which is quite close to that of McCallum (1975).

${ }^{5}$ See for example Abe et al. (1975); Akhtar (1974); Mangla (1979); Khan (1982); Gujrati (1968); Gupta (1970) and Singh (1970) for India, Wong (1977) and Khan (1982) for Sri Lanka and Naqui et al. (1984) for all the four countries.
} 
The results of the proposed shock-absorber model in Table 1 show that the money shock variable has a positive sign in all the equations. The OLS estimates for this variable are significant at the 95 percent level for Pakistan, India and Bangladesh. For Sri Lanka, the coefficient of the money shock variable is significant at the 90 percent level. The instrumental variable estimates show that once again this variable enters positively in all the equations. However, now it is significant only for Pakistan and India. ${ }^{6}$

Table 1 also shows that the coefficient of transitory income has also appeared with the correct positive sign for all the countries except for Bangladesh. This is true both for the OLS and instrumental variable estimates. The variable of transitory income is significant at the 95 percent level for India and it is significant at the 90 percent level for Sri Lanka. Finally, the coefficient of the lagged dependent variable is also significant and its size is less than unity in all the four cases. This result is consistent in the presence of the partial adjustment model.

In the same table, alternative specifications for the four countries are also reported. Instead of making any distinction between permanent income and transitory income, we have used measured income as a scale variable. ${ }^{7}$ The results of the equations have not changed the complexion of the earlier story as the money shock variable has not only appeared with a positive sign, it is significant as well. All other variables also have the correct sign. However, the explanatory power of the alternative equations is slightly less.

As far as fully anticipated changes in money supply are concerned, according to Carr and Darby (1981) these will be reflected in the price level expectations and, therefore, in nominal money demand. This hypothesis could not be verified in the present study. It may be important to note that the empirical verification of this hypothesis was not even reported by Carr and Darby (1981) in their original work. However, in their rejoinder to Mackinnon and Milbourne (1984) they have successfully attempted this.

\section{CONCLUSIONS}

In this paper an attempt has been made to empirically test the hypothesis that changes in money supply which are not fully anticipated affect the real money balances with a positive sign. Although this hypothesis was verified for eight industrial countries by Carr and Darby (1981), nevertheless, it required further empirical tests especially for the economies of developing countries. Here we have shown that in a shock-absorber model for countries of the South Asian region, the shock

\footnotetext{
${ }^{6}$ The equations estimated by OLS and also by instrumental variable technique are corrected for serial correlation by applying Cochrane-Orcutt technique, if and when it was present.

${ }^{7}$ In order to save ourselves from any problem that may arise out of the use of the simultaneous $Y_{t}^{T}$ and $M_{t}^{\mu}$, we have also tried alternative specification for every country.
} 


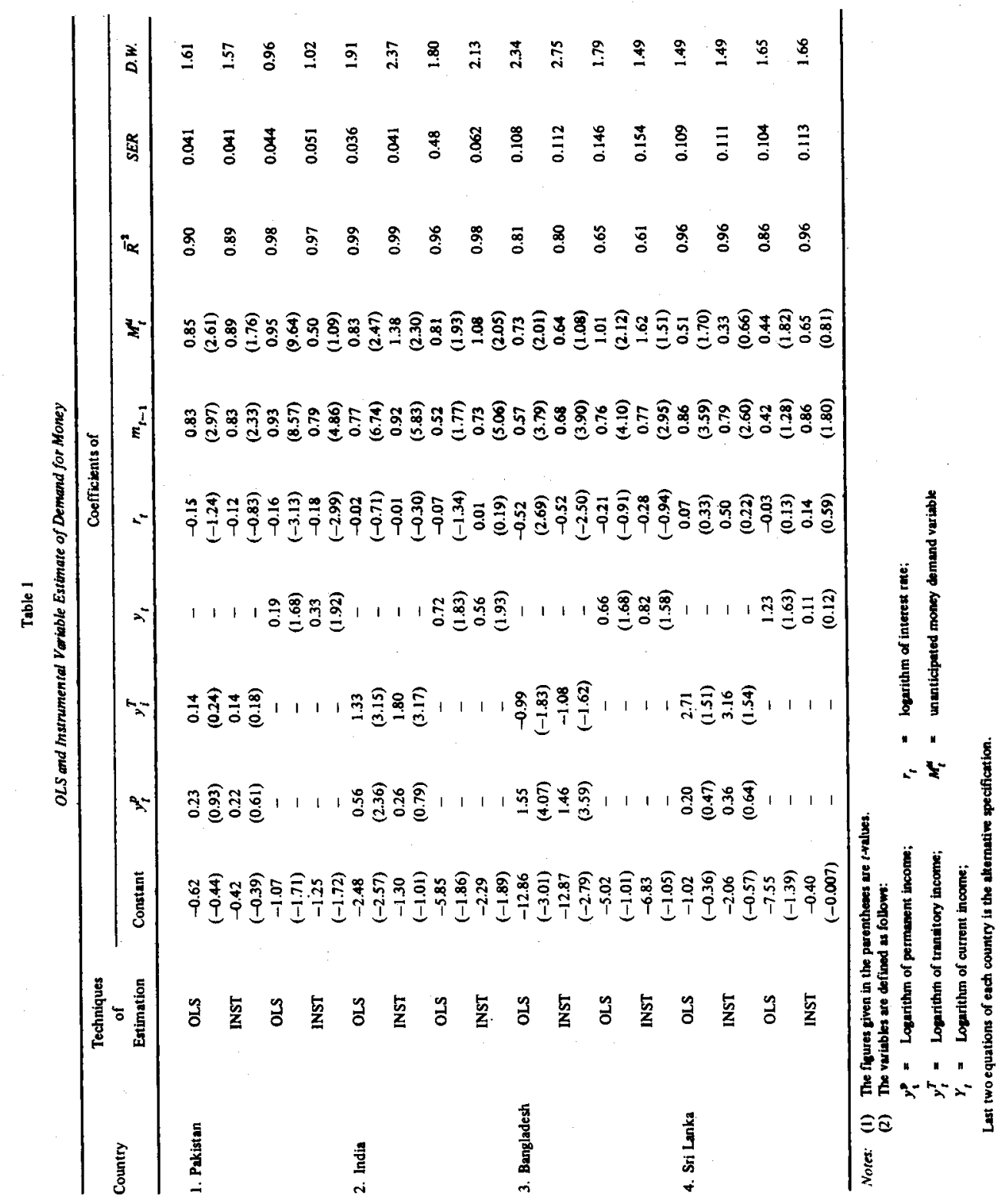


variable enters in all the equations with a positive sign. Furthermore, the coefficient of the transitory income is also positive and greater than zero for all except one case. This confirms that all unexpected variations of income, especially the transitory income, are absorbed by money balances until there is a final adjustment in the portfolio of securities. Towards the end it may be noted that the hypothesis that fully anticipated changes in money supply affect nominal money supply could not be verified in the present exercise.

\section{REFERENCES}

Abe, S., M. J. Fry, B. K. Min, P. Vongvipanond and I Yu (1975). "The Demand for Money in Pakistan: Some Alternative Estimates". Pakistan Development Review. Vol. XIV, No. 2.

Akhtar, M. S. (1974). "The Demand for Money in Pakistan". Pakistan Development Review. Vol. XIII, No. 1.

Cagan, P. (1956). "The Monetary Dynamics of Hyper-inflation". In Milton Friedman (ed.), Studies in the Quantity Theory of Money. Chicago: University of Chicago Press.

Carr, J., and M.R. Darby (1981). "The Role of Money Supply Shocks in the Shortrun Demand for Money". Journal of Monetary Economics. Vol. 8, No. 2.

Carr, J., M. R. Darby and D L. Thornton (1985). "Monetary Anticipations and the Demand for Money: Reply to Mackinnon and Milbourne". Journal of Monetary Economics. Vol. 16, No. 2.

Chow, G. C. (1966). "On the Long-run and Short-run Demand for Money". Journal of Political Economy. Vol. 74, No. 2.

Darby, M. R. (1972). "The Allocation of Transitory Income among Consumers" Assets". American Economic Review. Vol 62, No. 5.

Friedman, M. (1959). "The Demand for Money: Some Theoretical and Empirical Results". Joumal of Political Economy. Vol. LXVII,No. 4

Goldfeld, S. M. (1973). "The Demand for Money Revisited". Brookings Papers on Economic Activity. Vol. 3.

Gujrati, D. (1968). "The Demand for Money in India". Journal of Development Studies. Vol. V, No. 1.

Gupta, K. L. (1970). "The Demand for Money in India: Further Evidence".Journal of Development Studies. Vol. VI, No. 2.

Khan, A. H. (1982). "The Demand for Money in Pakistan: Some Further Results". Pakistan Development Review. Vol. XIX, No. 1.

Khan, Mohsin S. (1980). "Monetary Shocks and Dynamic of Inflation". IMF Staff Papers. Vol. 27.

Laidler, David (1977). The Demand for Money: Theories and Evidence. Second Edition. New York: Dun-Donnelley. 
Laidler, David (1980). "The Demand for Money in United States Yet Again". In On the State of Macro-Economics. Carnegie-Rochester Conference Series on Public Policy. Vol. 12.

Mackinnon, J. G., and R. S. Milbourne (1984). "Monetary Anticipatory and the Demand for Money ". Journal of Monetary Economics. Vol. 13, No. 2.

Mangla, I.U. (1979). "An Annual Money Demand Function for Pakistan: Some Further Results". Pakistan Development Review. Vol. XVIII, No. 1.

McCallum, B. T. (1975). "Rational Expectations and the Natural Rate Hypothesis: Some Evidence for the United Kingdom". Manchester School. Vol. 43, No. 4.

Naqvi, Syed Nawab Haider, A. M. Ahmed and A. H. Khan (1984). "Possibilities of Regional Trade Expansion: A Link Model for Pakistan, India, Bangladesh and Sri Lanka". Pakistan Development Review. Vol. XXIII, No. 1.

Rausser, G. C., and R. S. Laumas (1976). "The Stability of Demand for Money in Canada". Joumal of Monetary Economics. Vol. 2, No. 3.

Sargent, T. J. (1973). "Rational Expectations, the Real Rate of Interest and the Natural Rate of Unemployment". Brookings Papers in Economic Activity. Vol. 2.

Singh, B. (1970). "Price-Stability and Money Supply During Fourth Five Year Plan". Indian Economic Journal. Vol. 17, No. 45.

Wong, C. (1977). “ Demand for Money in Developing Countries". Journal of Monetary Economics. Vol. 3, No. 1. 


\section{Comments on \\ "Monetary Anticipation and the Demand for Money: An Application for the South Asian Region"}

The paper is a successful attempt to apply the Carr-Darby model to some of the Asian countries. Three major comments on the paper concerning its theoretical basis, specification of the model and the empirical estimates are in order:

1. The hypothesis, that unanticipated changes in money supply affect real money balances rather than the interest rate and price level, was tested by Carr-Darby for eight industrial countries. To put this hypothesis to further empirical testing for developing countries, the authors needed to establish the relevance for doing so by convincing the readers about the following queries:

(i) Are there really some changes in money supply which remain unanticipated in the developing countries?

(ii) If yes, how large is the size of such changes, i.e., are these changes significant enough to be considered separately in the demand for money?

(iii) Do the capital markets in the developing countries really provide a portfolio adjustment mechanism in the same fashion as they do in the case of industrial countries?

(iv) Do the communities in developing countries really have a feel for distinction between anticipated and unanticipated parts of money supply changes?

2. The unanticipated changes in money supply have been approximated in the paper by the residual of the equation regressing money supply on its past values alone. Estimates of this equation for all the four countries considered in the study turn out to be unstable as the coefficients of $M_{t-1}$ exceed unity. Moreover, the residual thus derived would be biased if there had been large money creation for budgetary support purposes mainly because a part of such money creation is anticipated. In view of this, it would be desirable to include in the equation, some measure of money creation required for federal financing needs. Barro (1977) used for this purpose, actual federal expenditure in excess of normal federal expenditure. As an alternative, actual budgetary support in excess of some average of the sample period may be used. 
3. In specifying the demand for money equation, the authors, simply follow the Carr and Darby specification and without realizing the difference of the money markets between the developed and developing countries, have used, inter alia, interest rate, transitory income, and unanticipated money supply. In developing countries, interest rates are often fixed by the monetary authorities and remain fixed over a fairly long period. In these circumstances it is not correct to use the interest rate as the market price of holding money. Secondly, if there is any such thing as unanticipated money supply at all, it would be highly correlated with the transitory income and, thus, the use of both the variables as regressors simultaneously, as has been done by the authors, seems highly unwarranted. The mis-specification of the model is manifested in the insignificant coefficients of both the interest rate and transitory income in most of the equations; transitory income is insignificant for all the countries except India and, similarly, the interest rate is insignificant for all the countries except Bangladesh.

Ministry of Finance, Shaukat Ali Islamabad

\section{REFERENCE}

Barro, R. J. (1977). "Unanticipated Money Growth and Unemployment in the U.S ". American Economic Review. Vol. 67, No. 1. 